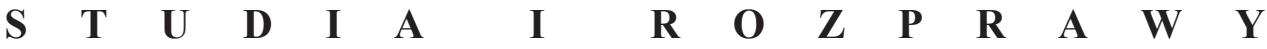

ROCZNIKI HUMANISTYCZNE

Tom LXVII, zeszyt $10-2019$

DOI: http://dx.doi.org/10.18290/rh.2019.67.10-1

\author{
KLAUDIA BĄCZYK-LESIUK
}

\section{DZIECKO OBCOJĘZYCZNE W POLSKIM PRZEDSZKOLU, CZYLI O (NIE)OGRANICZENIACH W EDUKACJI}

\author{
TYTUŁEM WSTĘPU
}

Procesy globalizacji obejmujące, jak się przekonaliśmy, wszystkie aspekty współczesnego życia społecznego - ekonomię, politykę, kulturę - znalazły odzwierciedlenie w świadomości społecznej. Znaczącej zmianie uległ sposób, w jaki ludzie postrzegają świat, zarówno ten lokalny, jak i świat jako całość. Pojawiły się nowe wizje; niektóre powstają na poziomie myślenia potocznego, inne są artykułowane przez określone ideologie globalizmu i antyglobalizmu ${ }^{1}$.

Temat migracji i wzajemnego przenikania się kultur od kilku lat staje się popularny również w Polsce, a ciągły napływ obcokrajowców okazuje się być zagadnieniem poruszanym w debacie publicznej, szczególnie w obszarach polityki i gospodarki. Rosnącą liczbę cudzoziemców w kraju widać wyraźnie w statystykach Eurostatu, według których Polska zajmuje drugie miejsce w Unii Europejskiej pod względem wydawanych wiz długoterminowych oraz zezwoleń pobytowych dla osób z państw trzecich (mianem tym określani są cudzoziemcy spoza Unii Europejskiej). Najliczniejszą grupą wnioskodawców odnośnie do wszystkich zezwoleń stanowią obywatele Ukrainy ${ }^{2}$. Poza nimi chętnie przybywają do Polski: Białorusini, Niemcy, Rosjanie, Wietnamczycy i Hindusi. Mimo

Dr Klaudia Bączyk-Lesiuk - adiunkt w Katedrze Edukacji i Nowych Mediów, kierownik Studiów Podyplomowych Edukacja Wczesnoszkolna i Przedszkolna, pełnomocnik Dziekana ds. studentów z zagranicy w Collegium Da Vinci w Poznaniu; e-mail: klaudia.baczyk-lesiuk@cdv.pl

${ }^{1}$ P. SzTompKa, Socjologia zmian społecznych, Kraków: Znak 2010, s. 101.

${ }^{2}$ Mowa tu o pobytach: czasowym, stałym i rezydenta długoterminowego Unii Europejskiej. Zob. Broszura podsumowująca rok obowiązywania ustawy o cudzoziemcach, https://udsc.gov. $\mathrm{pl} /$ statystyki/raporty-specjalne (dostęp: 25.11.2018). 
ciągłego zainteresowania przepływem ludności zdaje się, że nadal pomijana jest kwestia współpracy z dziećmi obcojęzycznymi, które coraz częściej spotkać można w polskich szkołach. Co prawda uczniowie obcojęzyczni otrzymują wsparcie edukacyjne (wynikające z rozwiązań wprowadzonych przez Ministerstwo Edukacji Narodowej), organizowane są dodatkowe lekcje języka polskiego, a od 2 lat istnieje także możliwość otwarcia klas przygotowawczych dla uczniów mających problemy komunikacyjne i adaptacyjne, jednakże wydaje się, że to wciąż zbyt mało. Ponadto temat ten jest całkowicie marginalizowany na etapie edukacji przedszkolnej, kiedy to w ogóle nie porusza się zagadnienia specjalnych potrzeb dzieci. W związku ze stale zmieniającą się sytuacją warto zastanowić się nad przygotowaniem osób, którym powierzony zostaje proces edukacyjny dzieci z doświadczeniem migracyjnym. Kim zatem winien być nauczyciel XXI wieku? Jaka jest jego rola w poszukiwaniu tożsamości w ponowoczesnej Europie? I gdzie w tym wszystkim pozostaje dziecko, nierzadko obarczone doświadczeniem migracyjnym?

\section{ZAŁOŻENIA METODOLOGICZNE}

\section{Cel Badań}

Podstawowy problem badawczy dotyczy poszukiwania odpowiedzi na pytania dotyczące ograniczeń w pracy z dzieckiem obcojęzycznym w przedszkolach w Polsce. Badaniu poddano pracowników zarówno placówek publicznych, jak i prywatnych, do których uczęszczają dzieci wielojęzyczne. Temat zostaje przedstawiony w kontekście: komunikacji werbalnej i niewerbalnej, oceniania ucznia oraz znajomości zagadnienia przez samych nauczycieli. W odniesieniu do powyższych zaprezentowane zostaną bariery w pracy z uczniem obcojęzycznym - zarówno te realne, jak i te istniejące jedynie w świadomości nauczycieli.

\section{Metody BADaŃ}

Podczas badań zastosowano dwie metody: sondaż diagnostyczny wśród nauczycieli edukacji przedszkolnej oraz wywiad indywidualny, który stanowił dopełnienie badania ilościowego, będąc wnikliwą analizą poszczególnych studiów przypadków. 


\section{BADANIA ANKIETOWE}

W badaniach zastosowano anonimowe ankiety środowiskowe. Łącznie przeprowadzono 100 ankiet wśród respondentów, z których połowa zatrudniona była w Poznaniu, natomiast pozostałe osoby jako miejsce pracy zaznaczały mniejsze miasta bądź wsie znajdujące się w województwie wielkopolskim (w powiatach: poznańskim, kościańskim i leszczyńskim). Pod uwagę brano zarówno przedszkola publiczne, jak i prywatne (które nie określały się jako dwujęzyczne). Ankieta rozdawana była nauczycielom osobiście przez badającego za zgodą dyrekcji w poszczególnych placówkach. Jednocześnie poinformowano wszystkich, że ankiety trafią do badającego i że nikt z dyrekcji nie będzie miał w nie wglądu. Wszystkim respondentom znana była jej tematyka - praca z uczniem obcojęzycznym. Ankieta składała się z 14 pytań dotyczących kilku obszarów związanych zarówno z wiedzą teoretyczną na temat ucznia z zagranicy (tu m.in. analizowano pojęcia: glottodydaktyki polonistycznej, bilingwizmu, rozwoju mowy u dzieci wielojęzycznych), jak i praktycznym doświadczeniem (komunikacja werbalna i niewerbalna, ocenianie, stosowane metody nauki języka polskiego, zjawisko integracji). Połowę stanowiły pytania zamknięte; w przypadku jednak, gdy dana kafeteria nie dostarczała dopasowanej do sytuacji odpowiedzi, istniała możliwość udzielenia odpowiedzi w polu ,inne”. Początkowa część zawierała podstawowe informacje na temat badanego: wiek, płeć, staż zawodowy, miejsce pracy. W pierwszej kolejności istotne było poznanie kwestii samego zagadnienia i jej świadomości wśród nauczycieli. Ważnym elementem było także dostrzeganie przez badanych różnicy $\mathrm{w}$ pracy $\mathrm{z}$ dzieckiem pochodzenia polskiego: monolingwalnym bądź bilingwalnym oraz cudzoziemskim. Pytano również o sposoby oceniania i udzielanie informacji zwrotnej w przypadku przedszkolaków obcojęzycznych. Respondenci chętnie opisywali problemy związane z komunikacją z opiekunami prawnymi, szczególnie w przypadku pojawienia się bariery językowej. Ponadto przedstawiali własne uwagi dotyczące obowiązującego prawa oświatowego (ze szczególnym uwzględnieniem zagadnień dotyczących dodatkowych zajęć dla dzieci cudzoziemskich).

\section{WYWIAD JAKO METODA BADAWCZA}

Podczas badań przeprowadzono 20 wywiadów z nauczycielami edukacji przedszkolnej. Połowa z nich odbyła się w Poznaniu, kolejne miały miejsce w mniejszych miejscowościach m.in. takich, jak: Kościan, Racot i Leszno. Przyjęta rozbieżność miejsc pozwoliła na dokładne zapoznanie się zarówno 
z przedszkolami miejskimi, jak i wiejskimi. Przyjmując taką metodę badawczą, uznano, że będzie ona: ustna, nieskategoryzowana, jawna ${ }^{3}$, indywidualna ${ }^{4}$. Całość była nagrywana, a dopiero później spisywana (co, zdaje się, zapewniło respondentom większy komfort rozmowy).

\section{RAPORT Z BADAŃ}

W badaniu ankietowym wzięło udział stu nauczycieli (z czego 98 to kobiety, 2 to mężczyźni). Ponad połowa z nich (63\%) to osoby powyżej 30 roku życia; każdy zaznaczył, że jest nauczycielem praktykującym (poniżej roku: 5 osób, 1-5 lat: 33 osoby, 5-10 lat: 51 osób, powyżej 10 lat: 11 osób), który pracował już z uczniem obcojęzycznym ${ }^{5}$. Wobec zastanego problemu nauczyciele przyjmowali dwie dominujące postawy: indyferentną bądź sentymentalną ${ }^{6}$. Nauczyciele charakteryzujący się postawą indyferentną zdawali się być obojętni wobec problemów wynikających z pracy z uczniem cudzoziemskim ${ }^{7}$. Swoje zachowanie

${ }^{3}$ Przed wywiadem respondenci zostali poinformowani o roli badającego oraz celowości przeprowadzanych badań.

${ }^{4} \mathrm{~W}$ tym przypadku wywiad nie mógł odbyć się zbiorowo. Istniało bowiem ryzyko, że respondenci nie będą chcieli publicznie dzielić się swoimi obawami oraz problemami wynikającymi (jak wykazano podczas badania ankietowego oraz wywiadów) z braku odpowiedniego przygotowania do pracy z uczniem wielojęzycznym. Taka forma została wykorzystana podczas badania przeprowadzonego przez autorkę na studentach jednego z kierunków pedagogicznych. Respondenci chętnie dzielili się wówczas swoimi lękami oraz wnioskami z odbytych praktyk, podczas których wielokrotnie stykali się z sytuacjami, które okazały się wyzwaniem zarówno wychowawczym, jak i edukacyjnym. Zgodnie stwierdzili, że na studiach przygotowujących do pracy w przedszkolu i klasach I-III brakuje przedmiotów, podczas których omawiane byłoby zagadnienie bilingwizmu. Część z nich (40\%) przyznała, że nie znają metod pracy z uczniem cudzoziemskim i nie wyobrażają sobie procesu edukacyjnego takiego dziecka. Respondenci obawiali się, że bariera komunikacyjna okaże się zbyt duża, by móc zintegrować grupę i należycie wywiązać się ze swoich obowiązków $(60 \%)$.

${ }^{5}$ Trzy osoby zaznaczyły, że pracowały z osobami obcojęzycznymi, dopisując, że były to dzieci posługujące się dwoma językami (polskim i rosyjskim). Wynikać może z tego, że respondenci uznali, że dzieci bilingwalne tożsame są z obcojęzycznymi. Według definicji słownikowej jednak „cudzoziemski” odnosi się tylko do obywateli obcego państwa, natomiast „bilingwalny” charakteryzuje osobę, która posługuje się dwoma językami (nie wskazując na jej pochodzenie). Stownik języka polskiego, https://sjp.pwn.pl/ (dostęp: 1.06.2019).

${ }^{6}$ Zob. P.B. Horton i G.R. Leslie, cyt. za: Wstęp do metod i technik badań społecznych, red. J. Sztumski, Katowice: Śląsk 2005, s. 48.

${ }^{7}$ Kilkakrotnie pojawiały się wypowiedzi typu: „Jesteśmy w Polsce, więc każdy powinien mówić po polsku”, „To rodzice powinni nauczyć dzieci języka”, „Za chwilę będzie się od nas wymagało pracy indywidualnej z każdym uczniem. W jaki sposób mamy to robić, mając ponad 20 osób w grupie?". 
usprawiedliwiali brakiem wiedzy na dany temat ${ }^{8}$, błędnymi zapisami w prawie oświatowym (w kontekście edukacji przedszkolnej) i niemożnością dokonania jakichkolwiek zmian. Często zdawali się być oburzeni faktem, że to ich rolą ma być nauka języka polskiego, nie rozumiejąc, że: „,w przeciwieństwie do rodziny, szkoła uczy utrwalania języka: jego zapisywania i czytania. Ucząc tworzenia tekstów pisanych, szkoła najpierw poszerza repertuar językowy, a potem uczy świadomego wyboru słów i struktur językowych" ". Nauczyciele przyjmujący postawę sentymentalną, pomimo swej niepełnej wiedzy, wyrażali natomiast chęć zaangażowania się w konieczny proces zmian w edukacji. Wykazywali się przy tym współczuciem dla dzieci, które często nie otrzymują odpowiedniego wsparcia w nauce (mowa tu o języku polskim) oraz zaangażowaniem (podkreślając własne próby w prowadzeniu zajęć integracyjnych).

Spośród wszystkich wypowiedzi ankietowych wyróżnić można następujące ograniczenia występujące w polskiej edukacji przedszkolnej w następstwie kontaktu z dzieckiem cudzoziemskim ${ }^{10}$ : 1 . Niedostateczne przygotowanie kadry pedagogicznej ${ }^{11}, 2$. Brak potrzebnych materiałów do nauki języka polskiego jako obcego $^{12}, 3$. Niedostateczna pomoc w procesie organizowania edukacji ze strony władz, przełożonych ${ }^{13}$, 4. Nieumiejętność doboru metod w pracy z dzieckiem

\footnotetext{
${ }^{8}$ Powtarzały się wypowiedzi typu: „Kiedy mam chodzić na dodatkowe szkolenia, skoro poza pracą mam też rodzinę?”, „Pracodawca nie sfinansuje mi warsztatów, a ze swoich nie będę dawać”, „Wczoraj dzieci z ADHD, dziś obcokrajowcy, za chwilę się okaże, że studia to za mało, by pracować w przedszkolu".

${ }^{9}$ W. Miodunka, cyt. za: E. Lipińska, Polskość w Australii. O dwujęzyczności, edukacji i problemach adaptacyjnych Polonii na antypodach, Kraków: Wydawnictwo UJ 2013, s. 109.

${ }^{10}$ Zbliżone trudności zaprezentowano w opracowaniu E. Obary-Grączewskiej, wykazując na ich następującą genezę: „brak przygotowania i doświadczenia w pracy z uczniami obcojęzycznymi; presję, by realizować podstawę programową i osiągać wysokie wyniki na egzaminach; zbyt dużą liczbę uczniów w klasie; obciążenia pracą; przekonania, że umiejętność podstawowej komunikacji nie zagwarantuje sukcesów edukacyjnych ze względu na problemy związane ze stosowaniem słownictwa specjalistycznego; zbyt małą liczbę godzin przeznaczoną na naukę języka polskiego jako obcego; łączenie na zajęciach różnych grup narodowościowych; niejasną procedurę oceniania postępów ucznia na wszystkich lekcjach" (E. OBARA-GrącZEWSKA, Uczeń obcojęzyczny w szkole, czyli nauczycielskie wyzwania i trudności, Warszawa: Ośrodek Rozwoju Edukacji 2018, s. 8-9.)

${ }^{11}$ Żaden z respondentów nie ukończył studiów z zakresu nauczania języka polskiego jako obcego. Dodatkowo wszyscy podkreślili, że na studiach nie zaproponowano im przedmiotu związanego z glottodydaktyką polonistyczną, w związku z czym nie czują się specjalistami w tej dziedzinie.

12 Tylko w pięciu ankietach wspomniano o książce do nauki języka polskiego jako obcego przeznaczonej dla dzieci (M. MaŁYsKa, Figlarna kredka, Ashford: Polonijne Centrum Edukacyjne Literka 2016). Pozostałe osoby podkreślały brak odpowiednich pozycji dla ucznia w edukacji przedszkolnej. Zarzut dotyczący braku materiałów pojawił się także w każdym z wywiadów.

${ }^{13}$ Respondenci wielokrotnie podkreślali swoją frustrację (70\%), powtarzając, że nikt z przełożonych nie tłumaczył im, w jaki sposób mają pracować z dzieckiem obcojęzycznym. Często dzieci po prostu pojawiały się w grupie, a nauczyciel nie był nawet świadomy pochodzenia swojego
} 
obcojęzycznym, 5. Brak rozgraniczenia pojęciowego między dziećmi bilingwalnymi a wielojęzycznymi (tu w szczególności zacieranie się granicy między dzieckiem obcojęzycznym a dwujęzycznym) ${ }^{14}, 6$. Brak asystenta międzykulturowego w przedszkolu, 7. Nieumiejętność diagnozowania potrzeb ucznia z doświadczeniem migracyjnym, 8. Niejasna procedura oceniania i udzielania informacji zwrotnej uczniom i rodzicom ${ }^{15}$, 9. Niemożność integracji dzieci pochodzących z różnych kręgów kulturowych, 10. Bariery kulturowe ${ }^{16}$.

\section{STUDIA PRZYPADKÓW ${ }^{17}$}

Zaprezentowane studia przypadków wpisują się w cykl wywiadów indywidualnych z nauczycielami przedszkoli, podczas których poruszono tematykę pracy z uczniem cudzoziemskim. Zdaje się, że choć zagadnienia związane z glottodydaktyką polonistyczną stają się coraz bardziej aktualne, nadal brakuje wystarczającego rozwiązania sytuacji edukacyjnej dzieci z doświadczeniem migracyjnym w przedszkolu. Poszczególne historie mogą stać się przyczynkiem do poszukiwania rozwiązania, odnalezienia się w nowej sytuacji edukacyjnej,

ucznia. Niewiedza stawała się przyczynkiem do stresujących sytuacji zarówno dla dzieci, jak i nauczycieli (46\% dodawało, że gdyby mieli wiedzę na temat ucznia obcojęzycznego, staraliby się: „,choć trochę przygotować i poczytać o innym kraju i kulturze”). Ponadto prezentowano sytuacje, w których nauczyciele uznawali, że nauka języka polskiego nie należy do ich obowiązków (problem zostaje szerzej opisany w Przypadku nr 1).

${ }^{14}$ Nauczyciele częstokrotnie (32\%) zauważali, że nie mają odpowiedniej wiedzy na temat rozwoju mowy u dzieci dwujęzycznych. Podkreślali (również w wywiadach), że zdarzają się sytuacje, kiedy nie wiedzą, czy dzieci posługują się neologizmami czy słowami pochodzenia obcego (z drugiego języka). W jednym z wywiadów przywołana została historia nauczycielki, która zaniepokojona odstępstwami od normy zgłosiła rodzicom problemy językowe ich syna. Zapomniała o dwujęzyczności dziecka i wychowywaniu go przez rodziców zgodnie z zasadą Grammonta. Podczas wywiadu przyznała, że po pierwszej rozmowie z dzieckiem nie zainteresowała się tematyką bilingwizmu i obce było jej wychowanie metodą One Parent-One Language, przez co ostatecznie stała się prowodyrem sytuacji stresującej zarówno dla niej, jak i rodziców ucznia (którzy początkowo zaniepokoili się opóźnieniem syna, a kolejno niewiedzą nauczycielki, która ma się nim zajmować).

${ }^{15}$ Respondenci zauważyli, że nie tylko kontakt z uczniami stanowi problem, ale również i rozmowa z ich rodzicami, którzy nie posługują się językiem polskim. Brak jednoznacznego rozwiązania powodował pomijanie opiekunów dzieci obcojęzycznych w rozmowach lub przekazywanie im niejasnych/szczątkowych komunikatów (w związku z czym dzieci nie były dostatecznie przygotowane na zajęcia).

${ }^{16}$ Problem istnienia barier kulturowych dokładniej zostaje opisany w Przypadku nr 2.

${ }^{17}$ Imiona wykorzystane w prezentowanych przypadkach są prawdziwe; zarówno nauczyciele, jak i dzieci/ich opiekunowie prawni wyrazili zgodę na ich wykorzystanie w artykule naukowym. 
pomocy zarówno dzieciom, jak i dorosłym. Dodatkowo mogą one wykazać ograniczenia edukacji, które wielokrotnie przekładają się na zachowania nauczycieli, pozostawiając ich niejako w sytuacji bez wyjścia.

Przypadek 1: Ignorowanie potrZeb eduKacyjnych uCZnia.

Wykonywany zawód: nauczycielka

Staż pracy: 6 lat

Miejsce pracy: przedszkole publiczne

Sylwia w swej pracy nigdy wcześniej nie spotkała się z uczniem cudzoziemskim, dlatego wyzwaniem okazało się dołączenie do jej grupy obywatela Armenii, Marata. Chłopiec wychowywany był dwujęzycznie, posługiwał się zarówno językiem armeńskim, jak i rosyjskim ${ }^{18}$. Nauczycielka postanowiła, że w związku z tym, że przedszkole jest publiczne, każde dziecko powinno płynnie posługiwać się językiem polskim; stwierdziła nawet: „Marat nie znał języka polskiego i co gorsze, nie uczył się go w domu. Moim obowiązkiem jest dbać o rozwój dzieci, a nie uczyć ich podstaw" ${ }^{19}$. Sądziła również, że niechęć rodziców ucznia do nauki języka polskiego zwalnia ją z obowiązku poświęcaniu mu dodatkowej uwagi ${ }^{20}$. Zdawała się nie dostrzegać, jak trudnym doświadczeniem było dla niego odnalezienie się w nowej grupie ${ }^{21}$. Chłopiec nie miał przyjaciół, nauczycielka natomiast (po pierwszych próbach kontaktu z dzieckiem) postanowiła, że nie

\footnotetext{
${ }^{18}$ Rodzice znali języki: armeński, rosyjski i angielski.

${ }^{19}$ Pisząc o roli nauczyciela, częstokrotnie zauważa się (tu w szczególności w kontakcie z uczniem obcojęzycznym), że winien on: „wprowadzać i oswajać ucznia z polską przestrzenią kulturową i społeczną. Nauczyciel poszerza przede wszystkim zasoby leksykalne uczniów, wspiera uzyskiwanie postępów w zakresie innych sprawności, ale także pomaga w realizacji zamierzeń związanych z nauką języka polskiego" (A. DĄBRowska, U. Dobesz, M. PAsIeKa, Co warto wiedzieć. Poradnik metodyczny dla nauczycieli języka polskiego jako obcego na Wschodzie, Warszawa: Ośrodek Rozwoju Edukacji 2010, s. 206).

${ }^{20} \mathrm{Na}$ zależność między wsparciem otoczenia a efektywną nauką zwraca uwagę Barbara Zurer Pearson: ,„...] pozytywne nastawienie rodziców, rodzeństwa i kolegów wobec danego języka może spowodować, że dziecko będzie ten język bardziej sobie cenić i stanie się on bardziej atrakcyjny w jego oczach. Język jako taki jest interesujący tylko dla językoznawców. Dla reszty język staje się atrakcyjny lub nie w zależności od tego, kto nim mówi i co w nim mówi” (B. Zurer Pearson, Jak wychować dziecko dwujęzyczne, przeł. Z. Wodniecka, K. Chlipalski, Poznań: Media Rodzina 2013, s. 174).

${ }^{21}$ Pójście do polskiego przedszkola czy szkoły zdaniem Romana Laskowskiego jest przeżyciem, kiedy to: „głęboko naruszone zostają podstawy, na jakich zbudowany był świat małego człowieka - staje się on niezrozumiały, obcy, a nawet wrogi” (R. LASKOwsKI, cyt. za: E. LiPIŃsKA, Polskość w Australii, s. 40).
} 
będzie angażowała go podczas zajęć, dając mu pełną swobodę. Ostatecznie bowiem uznała, że dziecko nauczy się języka poprzez obserwację i gdy będzie gotowe, to wtedy potraktuje je jak ,pełnoprawnego ucznia”. Sylwia nie czuła także presji ze strony kierownictwa przedszkola, które wprost mówiło: „chłopiec pójdzie do szkoły, a problem sam się rozwiąże”. Dziecko stało się ofiarą systemu szkolnictwa i ignorancji ze strony kadry przedszkola. Zupełnie zapomniano o zadaniach nauczyciela, który - wbrew poglądom Sylwii - jest przede wszystkim: ,przewodnikiem po świecie języka polskiego"22. W placówce doszło do marginalizacji potrzeb Marata, czego skutkiem mogą być problemy nie tylko edukacyjne, ale również społeczne i psychiczne.

Przypadek 2: Poczucie marginalizacji kultury i Języka W KONTEKŚCIE SOCJALIZACJI W NOWYM MIEJSCU.

Wykonywany zawód: nauczyciel przedszkola

Staż pracy: 3 lata

Miejsce pracy: przedszkole niepubliczne

Wiele spośród naszych codziennych zachowań osadzonych jest w normach kulturowych. Pochodzenie i wychowanie zdają się mieć ogromny wpływ na kształtowanie naszej tożsamości. Częstokrotnie to, co nieświadomie uważane jest za oczywistość, w innych częściach świata traktowane może być odmiennie, wywołując tym samym inne asocjacje. Anthony Giddens zauważa, że: „wartości i normy różnych kultur ogromnie się różnią. Podczas gdy jedne wysoko cenią indywidualizm, inne mogą kłaść większy nacisk na potrzeby wspólne"23. Pierwszy etap socjalizacji rozpoczyna się już w niemowlęctwie, kiedy to przekazywane są najważniejsze dla danej kultury normy i wartości (socjalizacja pierwotna), stając się tym samym podstawowym kanałem przekazu kulturowego. Zmiana miejsca zamieszkania, przeprowadzka do innego kraju może okazać się ciosem dla dziecka, które od początku przekonane jest o wyższości wpajanych mu norm i sposobów postępowania. Nagle bowiem, w obliczu nowej rzeczywistości, jego język, a także wzorce postępowania nie są już tak znaczące, ustępując miejsca nowym, obcym. W jaki sposób wyjaśnić to dziecku, by wraz ze swym zasobem kulturowym nie poczuło się marginalizowane? Jak zachować kulturę mniejszości, ucząc jednocześnie wzorców uznawanych przez większość? Przed

${ }^{22}$ A. Dąbrowska, U. Dobesz, M. Pasieka, Co warto wiedzieć, s. 206.

${ }^{23}$ A. Giddens, Socjologia, przeł. A. Szulżycka, Warszawa: Wydawnictwo Naukowe PWN 2008, s. 46. 
takim dylematem stanął Robert, nauczyciel, który od 3 lat pracuje w przedszkolu, łamiąc stereotyp jakoby praca $\mathrm{z}$ dziećmi była zajęciem typowo kobiecym. Zaczynał od prowadzenia dodatkowych zajęć z rytmiki, by w końcu przekonać do siebie dzieci, ich rodziców i dyrekcję. Podczas swojej pracy spotykał przede wszystkim uczniów pochodzenia polskiego, dlatego też chłopiec z Ukrainy okazał się dla niego sporym wyzwaniem pedagogicznym. Sasza chodził do grupy sześciolatków, bardzo dobrze mówił w języku polskim i zdawać by się mogło, że swym zachowaniem nie będzie odbiegał od rówieśników. Problem wynikał jednakże z barier kulturowych, których Robert w ogóle się nie spodziewał, powielając przekonanie o podobieństwie mentalnym Polaków i Ukraińców. Sasza na początku roku jako jedyny przyszedł elegancko ubrany, a każdemu z nauczycieli wręczył bukiet kwiatów. Był bardzo grzeczny i wyglądało na to, że nie do końca wiedział, w jaki sposób odnaleźć się w nowej sytuacji. Kilka tygodni trwało nim zaczął czuć się bardziej swobodnie, traktując przedszkole jako miejsce, gdzie nauka odbywa się poprzez zabawę. Nauczyciel starał się też wytłumaczyć rodzicom chłopca, że w polskim przedszkolu nie ma obowiązku dotyczącego eleganckiego stroju i że w razie konieczności będzie ich o tym informował. Robert nie chciał ingerować w sposób ubierania dziecka, jednakże czuł, że powinien zareagować, chroniąc je tym samym przed rolą odmieńca. Chłopiec wydawał się być bardzo zagubiony, tęskniąc za tym, co znał i czego został nauczony. Nie umiał zaakceptować tego, że ma uczyć się polskich piosenek i wierszy, brakowało mu literatury ukraińskiej. Czuł, że zdradza swoją ojczyznę, powtarzając zasłyszane zdania traktujące o Polsce i Polakach. Branie udziału w różnego rodzaju uroczystościach traktował jak grę, podczas której stawał się jednym z aktorów. Wydaje się, że bał się, iż postępuje niewłaściwie, odwracając się od kultury, w której się urodził. Robert chciał stać się przewodnikiem chłopca po tym nowym, często obcym świecie. Wiedział, że równorzędny dialog kulturowy, wymiana doświadczeń mogą wiele wnieść nie tylko do życia ucznia, ale i jego własnego. Wierzył w słuszność wielokierunkowego przepływu, uznając, że kontakt z inną kulturą pozwoli na: „zwiększenie kreatywności, wypełnienie globalnych form lokalnymi treściami. Lokalne wartości kulturowe mogą rozwinąc się i wzbogacać w tych nowych ramach" 24 . Nauczyciel obawiał się, że w wyniku braku zrozumienia Sasza poczuje, że jego kulturę uznaje się za gorszą, zmuszając go tym samym do porzucenia dawnych ideałów na rzecz nowych, polskich. Dodatkowym problemem okazała się także trudność w nawiązaniu relacji z dzieckiem. Sasza nie widział w Robercie mentora, a jedynie nauczyciela, który w razie nieposłuszeństwa doniesie na niego rodzicom bądź

\footnotetext{
${ }^{24}$ P. Sztompka, Socjologia, s. 100.
} 
użyje przemocy. Okazało się bowiem, że chłopiec przez pół roku chodził do przedszkola na Ukrainie, gdzie jednym ze sposobów karania było bicie po rękach. Robert, pomimo starań, nie potrafił przekonać chłopca o swych dobrych zamiarach. Zdawał sobie sprawę, że Sasza poznał innego rodzaju przedszkole, przyzwyczaił się do innych zachowań ze strony przedstawicieli edukacji oraz wyrósł w odmiennej kulturze, którą bał się stracić.

\section{PODSUMOWANIE}

Problemy poruszone przez osoby pracujące w przedszkolu zdają się reprezentować powszechnie panujące niepokoje dotyczące pracy z uczniem obcojęzycznym. Studia przypadków powstałe w następstwie wywiadów oraz wyniki badań ankietowych stają się przyczynkiem do pytania o rolę drugiego (kolejnego) języka w polskim środowisku przedszkolnym. Czy istnieją granice edukacji? Kim w globalizującym się świecie staje się nauczyciel? Jaka jest jego rola w programie kulturowego przepływu? Wydaje się, że opisane bariery wpisują się w wyzwania, przed którymi stają nie tylko pracownicy przedszkoli, ale również i władza. Pomijanie edukacji przedszkolnej w rozporządzeniach, brak dodatkowych godzin na zajęcia uzupełniające czy niewiedza dotycząca pracy z uczniem cudzoziemskim mogą skutkować (a jak wynika z badań - skutkują) podejściem cynicznym, postawą indyferentną. Nauczyciele wielokrotnie uznają, że nauka języka dzieci z zagranicy nie należy do ich obowiązków (szczególnie gdy pracują w przedszkolach publicznych), potwierdzając stereotypowe przekonanie jakoby w Polsce warunkiem koniecznym było posługiwanie się tylko i wyłącznie językiem polskim. Osoby te często nie są świadome negatywnych konsekwencji ich obojętnego, a niekiedy i wrogiego postępowania. W badaniach pojawiło się także wiele głosów nauczycieli, którzy choć świadomi własnej niewiedzy, zainteresowani są tematyką glottodydaktyki polonistycznej. Lęk wywoływany nową sytuacją częstokrotnie okazuje się blokadą uniemożliwiającą odnalezienie się w nowej sytuacji pedagogicznej. Dodatkowo istotnym ograniczeniem okazuje się brak odpowiedniego wsparcia ze strony przełożonych (którzy m.in.: ignorują temat, nie finansują szkoleń, nie informują o pochodzeniu uczniów i specjalnych potrzebach wynikających z migracji uczniów). Czy sytuacja panująca obecnie w polskich przedszkolach jest zatem do zaakceptowania? Zdaje się, że idealnym rozwiązaniem byłoby posłuchać nauczycieli przedszkoli, którzy wielokrotnie sami poruszają temat ograniczeń w edukacji. Polepszenie systemu edukacji mogłoby sprawić, że spotkanie z uczniem obcojęzycznym przestałoby budzić negatywne asocjacje, stając się inspirującym treningiem międzykulturowym. 


\section{BIBLIOGRAFIA}

Broszura podsumowująca rok obowiązywania ustawy o cudzoziemcach, https://udsc.gov.pl/ statystyki/raporty-specjalne (dostęp: 25.11.2018).

Dąbrowska A., Dobesz U., Pasieka M., Co warto wiedzieć. Poradnik metodyczny dla nauczycieli języka polskiego jako obcego na Wschodzie, Warszawa: Ośrodek Rozwoju Edukacji 2010.

Giddens A., Socjologia, przeł. A. Szulżycka, Warszawa: Wydawnictwo Naukowe PWN 2008.

Lipińska E., Polskość w Australii. O dwujęzyczności, edukacji i problemach adaptacyjnych Polonii na antypodach, Kraków: Wydawnictwo UJ 2013.

OBara-Graczewska E., Uczeń obcojęzyczny w szkole, czyli nauczycielskie wyzwania i trudności, Warszawa: Ośrodek Rozwoju Edukacji 2018.

Słownik języka polskiego, https://sjp.pwn.pl/ (dostęp: 1.06.2019).

Sztompka P., Socjologia zmian społecznych, Kraków: Znak 2010.

Wstęp do metod i technik badań społecznych, red. J. Sztumski, Katowice: Śląsk 2005.

Zurer Pearson B., Jak wychować dziecko dwujęzyczne, przeł. Z. Wodniecka, K. Chlipalski, Poznań: Media Rodzina 2013.

\section{DZIECKO OBCOJĘZYCZNE W POLSKIM PRZEDSZKOLU, CZYLI O (NIE)OGRANICZENIACH W EDUKACJI}

\section{Streszczenie}

Od kilku lat widać w Polsce rosnącą liczbę cudzoziemców. Co ciekawe, do naszego kraju przybywają już nie tylko pracownicy sezonowi, ale jak wynika z badań Eurostatu, osoby decydujące się na stały pobyt, kupujące mieszkania, zakładające rodziny. W kontekście globalizacji kultury warto zatem zastanowić się nad stanem polskiej edukacji, ze szczególnym uwzględnieniem edukacji przedszkolnej. Co państwo może zaoferować dzieciom uczącym się języka polskiego jako obcego/drugiego? Jak w tej nowej sytuacji edukacyjnej odnajdują się nauczyciele? Kim tak naprawdę staje się osoba pracująca w przedszkolu: nauczycielem, mentorem, strażnikiem tożsamości, logopedą, psychologiem czy po prostu towarzyszem? Praca koncentruje się wokół problemów zgłaszanych przez nauczycieli w następstwie kontaktu z uczniem imigracyjnym w przedszkolu. Przedstawione studia przypadków staną się asumptem do pytania o potrzebę zmian w obliczu wyzwań ponowoczesnej Europy.

Słowa kluczowe: dydaktyka; wielokulturowość; migracja; przedszkole; edukacja dzieci imigracyjnych.

\section{A FOREIGN LANGUAGE CHILD IN A POLISH KINDERGARTEN, ABOUT (UN) RESTRICTIONS IN EDUCATION}

\section{S u m m a r y}

For several years, a growing number of foreigners have been seen in Poland. Interestingly, not only seasonal workers come to Poland, but according to Eurostat research, these are people who decide to stay permanently, buy apartments, start families. In the context of the globalization of culture, it is worth considering the state of Polish education, with a particular emphasis on 
the pre-school education. What can the state offer to children who learning Polish as a foreign/ second? How do teachers find themselves in this new educational situation? Who is really a person working in a kindergarten: a teacher, a mentor, a guardian of identity, a speech therapist, a psychologist or just a companion? The work focuses on problems reported by kindergarten teachers as a result of contact with an immigrant student in kindergarten. The presented case studies will become an answer to the question about need for change in postmodern Europe.

Key words: didactic; multiculturalism; migration; kindergarten; education of immigrant children. 